Table 1 A comparison of ocular features of congenital varicella syndrome and herpes zoster ophthalmicus

\begin{tabular}{|c|c|}
\hline $\begin{array}{l}\text { Ocular features of congenital } \\
\text { varicella syndrome } e^{1017} 18\end{array}$ & $\begin{array}{l}\text { Ocular features of herpes zoster } \\
\text { ophthalmicus } 21\end{array}$ \\
\hline $\begin{array}{l}\text { Cicatrising dermatomal skin } \\
\text { lesions }\end{array}$ & $\begin{array}{l}\text { Cicatrising dermatomal skin } \\
\text { lesions and ptosis }\end{array}$ \\
\hline Chorioretinitis & Mucopurulent conjunctivitis \\
\hline Optic atrophy & Episcleritis and scleritis \\
\hline Anisocoria & Corneal anaesthesia \\
\hline Nystagmus & Recurrent keratitis \\
\hline Microphthalmia & Uveitis \\
\hline Cataract & Iris atrophy \\
\hline Corneal opacity & Glaucoma \\
\hline Heterochromia & $\begin{array}{l}\text { Ciliary ganglionitis causing } \\
\text { abnormal pupil response } \\
\text { Optic neuritis }\end{array}$ \\
\hline
\end{tabular}

Ophthalmologists will be interested in another distinct teratogenic effect of varicella zoster. The virus once acquired in pregnancy is able to cross the placenta causing systemic and ocular problems in the offspring. This association was first noted in $1947^{15}$ and has subsequently been recognised as the congenital varicella syndrome or the fetal varicella syndrome. ${ }^{1016-18}$ The ocular associations of congenital varicella and shingles are depicted in Table 1. The case we have described does not show many of the ocular findings in congenital varicella syndrome but does illustrate many of the clinical features of adult herpes zoster ophthalmicus: a dermatomal skin lesion in the distribution of the ophthalmic division of the trigeminal nerve, absent corneal sensation, recurrent keratitis and uveitis, iris atrophy, and abnormal direct pupil response. Other conditions that may cause skin defects are direct pressure on the fetus in utero or cutaneous polyarteritis, a rare vasculitis in children. ${ }^{19}$ However, the dermatomal distribution and ocular features make these latter two conditions unlikely.

In conclusion, we suspect that the mother's varicella infection in pregnancy and the child's congenital conditions are causally related. The varicella zoster virus probably crossed the placenta to lie dormant in the child's trigeminal ganglion. At some time before birth the virus was reactivated ${ }^{20}$ and led to this unique case of 'presumed herpes zoster ophthalmicus' in utero which was present at birth. The clinical findings are so unusual and similar to adult herpes zoster ophthalmicus, that this seems the most likely explanation.

1 Weller TH. Varicella and herpes zoster. Changing concepts of the natural history, control and importance of a not-so benign virus. $N$ Engl f Med 1983; 309: 1362-8; 1434-40.

2 Liesegang TJ, Rochester MN, The varicella zoster virus. Systemic and ocular features. $f$ Am Acad Dermatol 1984; 11 : 165-91.

3 Bonar BE, Pearsall CJ. Herpes zoster in the newborn. Am $\mathcal{F}$ Dis Child 1932; 44: 398-402.

4 Brunell PA, Miller LH, Lovejoy F. Zoster in children. Am f Dis Child 1968; 115: 432.

5 Lyday JH. Report of severe herpes zoster in a 131/2 year old boy whose chicken pox infection may have been acquired in whose chicken pox infection may
utero. Pediatrics 1972; 50: 930-1.

6 McKendrick DGW, Raychoudhury SC. Herpes zoster in childhood. Scand f Infect Dis 1972; 4: 23.

7 Lewkonia IK, Jackson AA. Infantile herpes zoster after intrauterine exposure to varicella. $B M \mathcal{F}$ 1973; $3: 149$.

8 Brunell PA, Kotchmar GS. Zoster in infancy: failure to maintain virus latency following intrauterine infection. f Pediatr 1981; 98: 71-3.

9 Dwonsky $M$, Whitley $R$, Alford C. Herpes zoster in early

infancy. $A m \mathcal{F}$ Dis Child $1980 ; 134: 618$.
10 Gershon AA. Chicken pox, measles and mumps. In: Remington JS, Klein JO, eds. Infectious diseases of the fetus and newborn infant. 3rd ed. 1990: 395-445.

11 David TJ, Williams ML. Herpes zoster in infancy. Scand $f$ Infect Dis 1979; 11: 185-6.

12 McMurray JB. Herpes zoster ophthalmicus in an infant of 15 months. Am f Ophthalmol 1928; 11: 51 .

13 Kock FLP. Herpes zoster ophthalmicus - report of a case. Arch Ophthalmol 1939; 21: 118-20.

14 Adkisson MA. Herpes zoster in a newborn premature infant. $\mathcal{F}$ Pediatr 1965; 66: 956-8.

15 La Foret, Lynch LL. Multiple congenital defects following maternal varicella. $N$ Engl f Med 1947; 236: 534-7.

16 Strabstein JC, Morris N, Larke RBP. Is there a congenital varicella syndrome? F Pediatr 1974; 84: 239-43.

17 Charles NC, Bennett TW, Margolis S. Ocular pathology of the congenital varicella syndrome. Arch Ophthalmol 1977; 95: 2034-7.

18 Alkalay AL, Pomerance JJ. Fetal varicella syndrome. f Pediatr 1987; 111: 320-3.

19 Forfar and Ameil's Textbook of Paediatrics. 4th ed. 1992: 1683-6.

20 Higa K, Dan K, Manabe H. Varicella zoster virus infections during pregnancy: hypothesis concerning the mechanism of congenital malformations. Obstet Gynecol 1987; 69: 214-22.

21 Karbassi M, Raizman MB, Schuman JS. Herpes zoster ophthalmicus. Surv Ophthalmol 1992; 36: 395-410.

\title{
Orbital multiple myeloma mimicking acquired angio-oedema
}

Medical University of
South Carolina
Department of
Dermatology
R L Snider
B H Thiers
Department of
Ophthalmology
G R Howard
Correspondence to:
Rebecca L Snider, MD,
Department of Dermatology,
Medical University of South
Carolina, 171 Ashley Ave, CSB
623, Charleston, SC 29425-
2215, USA.
Accepted for publication
8 March 1993

\author{
Rebecca L Snider, Bruce H Thiers, Gene R Howard
}

Multiple myeloma is characterised by malignant plasmacytes in the bone marrow and excessive production of specific immunoglobulins or immunoglobulin components. Ocular involvement may result from myelomatous infiltration or may occur secondarily to haematological abnormalities. Virtually any ocular structure can be involved, including the conjunctiva, cornea, sclera, lens, retina, uveal tract, optic nerve, lacrimal glands, and orbit. ${ }^{1}$ Involvement of periorbital skin is unusual. To our knowledge this is the first reported case of metastatic multiple myeloma presenting as periorbital swelling with angio-oedema-like features.

\section{Case report}

A 58-year-old white woman presented to her 


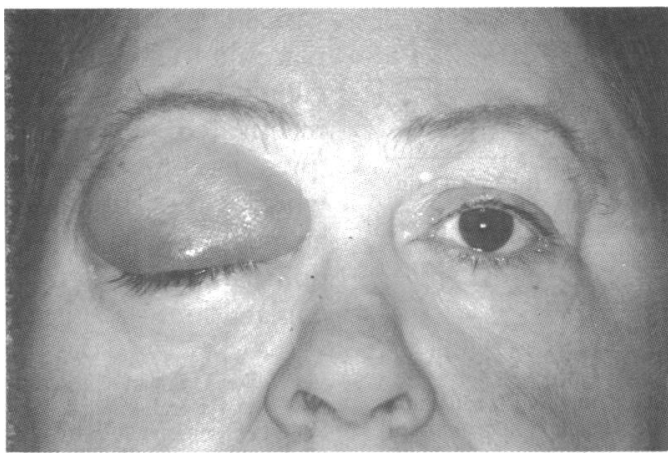

Figure 1 Angio-oedema of right upper eyelid. Note absence of involvement of right lower eyelid.

ophthalmologist with mild erythema and oedema of her upper right eyelid. A presumptive diagnosis of an allergic process was made during the initial examination and she was treated with oral antihistamines. Over the next 2 weeks the right upper eyelid oedema and erythema progressively increased. There were no associated symptoms of pain, epiphora, or pruritus. The medical history was significant for IgA $x$ multiple myeloma stage III, for which she was currently undergoing her third month of interferon alfa therapy. No history of trauma or infection was noted. Two weeks after the initial development of eyelid oedema, the patient was seen by her oncologist and immediately referred for dermatological and a separate ophthalmic examination.

On examination, the right upper eyelid was markedly oedematous with a yellow-orange translucent appearance (Fig 1). The best corrected visual acuity was $20 / 400$ in the right eye and $20 / 20$ in the left eye. The right pupil was $3 \mathrm{~mm}$, sluggishly reactive, and had a $2+$ afferent pupillary defect. Motility of the right eye was decreased in all fields of gaze (Fig 2). The conjunctiva had clear chemosis on the right side. The remainder of the anterior segment examination was normal. Examination of the fundus showed multiple flame-shaped retinal haemorrhages without disc oedema. Hertel exophthalmometry showed $6 \mathrm{~mm}$ of proptosis on the right. The right globe was inferiorly displaced by 8 $\mathrm{mm}$. Examination of the left eye and periorbital tissue was normal. Computed tomography (CT) examination of the orbits demonstrated an intraconal and extraconal infiltrating mass (Fig 3).

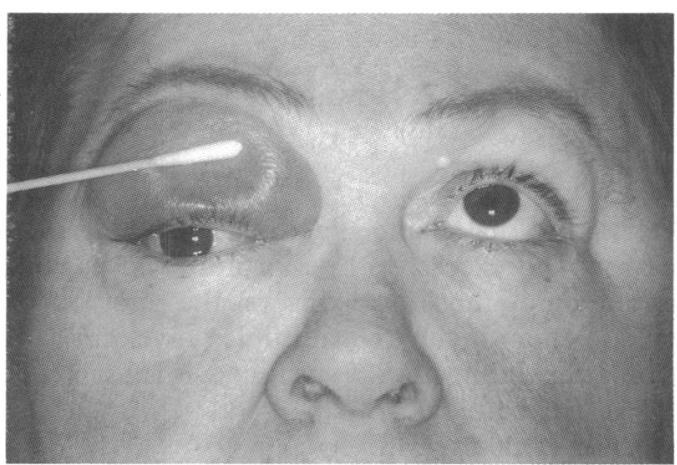

Figure 2 Pitting oedema of right upper eyelid and right hypotropia.

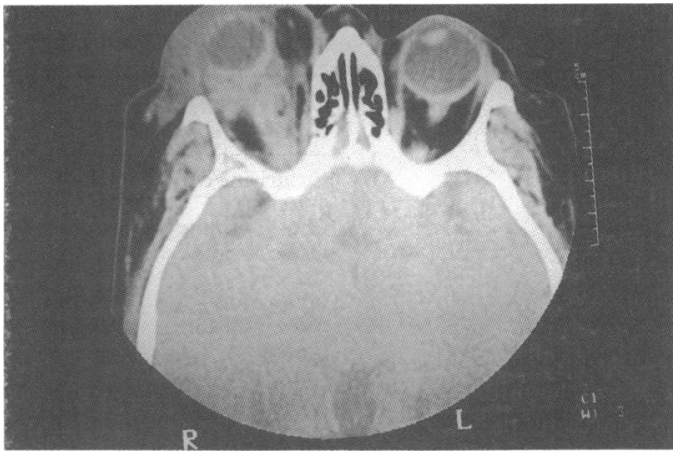

Figure 3 Axial CT scan demonstrating diffuse infiltration of the intraconal space, extraconal space, and eyelid on the right side.

There was no evidence of orbital bone involvement. Innumerable small lytic foci in the calvarium were consistent with diffuse involvement by multiple myeloma.

A diagnosis of metastatic multiple myeloma was made based on the radiological studies and the clinical history. The patient received radiation therapy ( $2500 \mathrm{~Gy}$ in 10 treatments over 14 days). One month after radiation therapy, the visual acuity of the right eye improved to 20/40 with marked regression of eyelid oedema and proptosis (Fig 4).

\section{Comment}

Specific cutaneous manifestations of multiple myeloma include extramedullary plasmacytomas of the skin and mucous membranes or, more commonly, may result from direct extension of primary bone lesions. Non-specific cutaneous manifestations include primary amyloidosis, changes secondary to cryoglobulins, changes secondary to anaemia, leucopenia, or thrombocytopenia, toxic eruptions, and changes secondary to internal organ involvement. ${ }^{23}$

Ocular manifestations may also be due to direct infiltration of the neoplasm (primary or metastatic) or from associated haematological changes. Progressive proptosis is occasionally the initial presentation of multiple myeloma, and is a common symptom when there is any involvement of the eye. Other symptoms include diplopia, pain, and visual loss. Signs of ocular involvement consist of large dilated fundal veins with flame-shaped and punctate haemorrhages. Cysts of the ciliary body and pars plana are also

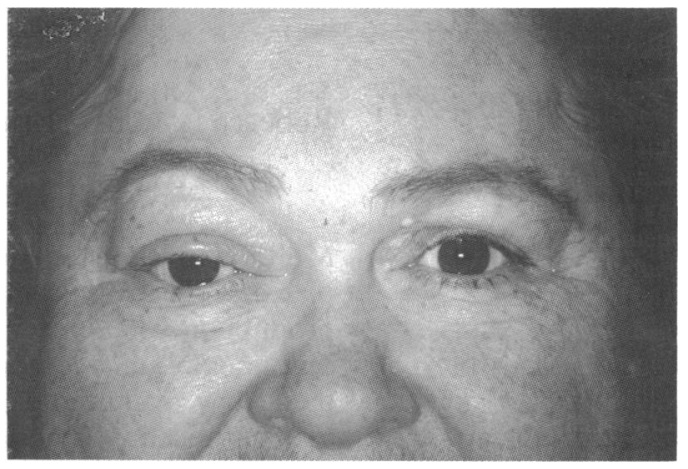

Figure 4 One month post-radiation treatment to the right orbit. Note the marked reduction in angio-oedema of the right eyelid and partial resolution of the right hypotropia. 
seen. ${ }^{46}$ Although the periorbital skin is rarely involved, Gudas reported a case presenting as periorbital cellulitis. ${ }^{7}$ The infection was presumed to be secondary to the patient's compromised immunological status.

Our patient presented with metastatic multiple myeloma and periorbital findings consistent with angio-oedema. This has not been described in the literature previously. Acquired forms of angio-oedema are known to be induced by physical agents, $\mathrm{Cl}$ esterase inhibitor autoantibodies, excessive consumption of $\mathrm{Cl}$ esterase inhibitor in lymphoproliferative disorders, and drug-induced inhibition of degradation of kininlike products of $\mathrm{Cl}$ esterase. ${ }^{8}$ Acquired angiooedema has not been reported as a side effect of interferon alfa therapy and is unlikely to be the aetiology in this case. We presume the angio- oedema-like features in our patient were secondary to the mass effect of the retro-orbital tumour causing obstruction of venous and lymphatic drainage from the periorbital skin.

1 Ashton N. Ocular changes in multiple myelomatosis. Arch Ophthalmol 1965; 73: 487-93.

2 Bluefarb SM. Cutaneous manifestations of multiple myeloma. Arch Dermatol 1955; 72: 506-22.

Jorrizo JL, Gammon WR, Briggaman RA. Cutaneous plasmacytomas. F Am Acad Dermatol 1979; 1: 59-66.

4 Maisel JM, Miller F, Sibony PA, Maisel LM. Multiple myeloma presenting with ocular inflammation. Ann Ophthalmol 1987; 19: 170-4.

5 Rodman HI, Font RL. Orbital involvement in multiple myeloma. Arch Ophthalmol 1972; 87: 30-5.

6 Clarke E. Plasma cell myeloma of the orbit. $\mathrm{Br} \mathcal{F}$ Ophthalmol 1953; 37: 543-4.

7 Gudas PP. Optic nerve myeloma. Am f Ophthalmol 1971; 71: 1085-9.

8 Greaves $M$, Lawlor F. Angioedema: manifestations and management. $\mathcal{F}$ Am Acad Dermatol 1991; 25: 155-65. 